\title{
Instagram dan Prokrastinasi Akademik Bagi Mahasiswa Universitas Gunadarma Saat Pandemi Covid 19
}

\author{
Edy Prihantoro, Susilowati Dyah K, Noviawan Rasyid Ohorella \\ Magister Ilmu Komunikasi, Universitas Gunadarma \\ noviawanrasyid@gmail.com
}

\begin{abstract}
Abstrak
Prokrastinasi menjadi suatu fenomena baru di kalangan mahasiswa. Munculnya berbagai platform media sosial yang mudah diakses mempengaruhi mereka untuk menunda pekerjaan atau tugas utama mereka untuk kuliah dan mengerjakan tugas. Mereka sengaja melakukan prokrastinasi untuk sekedar melihat media sosial atau mengalihkan perhatiannya untuk berbagi cerita dengan mahasiswa lainnya. Penelitian ini untuk mengetahui pengaruh media sosial Instagram terhadap prokrastinasi akademik mahasiswa. Prokrastinasi semakin rentan terjadi pada mahasiswa yang sedang mencari jati diri dan kejenuhan belajar pada saat PJJ (Pendidikan Jarak Jauh) sebagai akibat pandemic covid 19. Metode yang digunakan oleh peneliti adalah deskriptif kualitatif dimana peneliti melakukan observasi, wawancara, dan dokumentasi terhadap 6 informan yang dipilih berdasarkan beberapa kriteria. Teori yang digunakan dalam penelitian adalah Teori Uses and Gratification, sedangkan paradigma yang digunakan dalam penelitian ini adalah paradigma konstruktivis. Hasil dari penelitian ini adalah menunjukkan bahwa Instagram adalah salah satu media yang menjadi pilihan mashasiswa dan berperan besar dalam timbulnya prokrastinasi akademik. Berbagai fitur yang menarik pada Instagram, kemudahan untuk mengakses Instagram, dan Kejenuhan mahasiswa saat PJJ sebagai dampak Pandemi Covid19, menjadi alasan yang paling kuat sehingga mendorong mahasiswa melakukan prokrastinasi akademik.
\end{abstract}

Kata Kunci : Prokrastinasi Akademik, Instagram, Pandemi Covid19.

\begin{abstract}
Procrastination is a new phenomenon among students. The emergence of various easily accessible social media platforms influences them to postpone their work or main tasks for college and doing assignments. They deliberately procrastinate to just look at social media or divert their attention to share stories with other students. This study was to determine the effect of Instagram social media on student academic procrastination. Procrastination is increasingly prone to occur in students who are looking for identity and learning boredom during PJJ (Distance Education) as a result of the covid 19 pandemic. The method used by the researcher is descriptive qualitative where the researcher conducts observations, interviews, and documentation of 6 selected informants. based on several criteria. The theory used in this research is Uses and Gratification Theory, while the paradigm used in this research is the constructivist paradigm. The results of this study indicate that Instagram is one of the media of choice for students and plays a major role in the emergence of academic procrastination. Various interesting features on Instagram, the ease of accessing Instagram, and student boredom during PJJ as a result of the Covid19 Pandemic, are the strongest reasons that encourage students to do academic procrastination.
\end{abstract}

Keywords: Academic Procrastination, Instagram, Covid19 Pandemic. 


\section{Introduction}

Prokrastinasi adalah sebuah tindakan melakukan pekerjaan yang tidak penting dan mengabaikan pekerjaan utama. Tindakan prokrastinasi menurut sebuah penelitian di Jerman dan Austria sebagai kegagalan pengaturan atau regulasi diri. Timothy Phychyl (2012) dari Carleton University Canada menyatakan bahwa prokrastinasi adalah permasalahan regulasi diri. Menurutnya, seseorang mengetahui apa saja yang harus dikerjakan, tetapi tidak dapat mendorong diri sendiri untuk melakukan usaha tersebut. Mereka lebih senang mengerjakan hal-hal yang mudah dan menyenangkan, dan menunda pekerjaan atau tugas utama mereka. Mereka sadar tetapi tetap melakukan hal ini termasuk para mahasiswa tingkat akhir.

Mahasiswa adalah sosok yang dinamis dan memiliki sikap ilmuwan, yang melihat sesuatu berdasarkan kenyataan objektif, sistematis, dan rasional (Siregar, 2006). Mahasiswa sebagai masyarakat kampus yang memiliki tugas utama belajar, melakukan penelitian, dan kegiatan-kegiatan lainnya yang bercorak kekampusan (Siallagan, 2011). Mahasiswa juga memiliki tugas sebagai agen perubahan dan pengontrol sosial masyarakat, sehingga harapan besar ada di pundak mereka. Tugas yang berat seringkali membuat mahasiswa memilih dan menunda tugas yang berat dan perlu konsentrasi, dan cenderung mengerjakan tugas-tugas ringan atau bermain media sosial. Fenomena ini semakin menarik terjadi pada mahasiswa tingkat akhir yang sedang menyelesaikan tugas akhir, sehingga kondisi penyelesaian tugas akhir dan tugas lainnya menjadi pemicu mahaiswa "lari dari kenyataan" untuk mencari hiburan sehingga tidak stress.

Menurut Nasrullah (2015) media sosial adalah medium di internet yang memungkinkan pengguna merepresentasikan dirinya maupun berinteraksi, bekerja sama, berbagi, berkomunikasi dengan pengguna lain membentuk ikatan sosial secara virtual. Dalam media sosial, 3 bentuk yang merujuk pada makna bersosial adalah pengenalan (cognition), komunikasi (communicate) dan kerjasama (cooperation). Media sosial menjadi salah satu media bagi mahasiswa untuk berkomunikasi dan sharing pengetahuan. Hal ini berdampak pada berbagai sisi kehidupan mahasiswa. Kehadiran media sosial khususnya instagram telah membawa dampak yang sangat signifikan dalam cara melakukan komunikasi.

Peneliti mengambil media sosial Instagram karena akun Instagram adalah akun media sosial yang paling banyak digunakan di kalangam mahasiswa Gunadarma khusunya para Informan. Peneliti mengambil mahasiswa khususnya Mahasiswa tingkat akhir karena Mahasiswa tingkat akhir yang banyak mengalami prokrastinasi akadermik karena menggunakan media sosial Instagram. 
Seiring terjadinya revolusi soal cara berkomunikasi, masyarakat khususnya mahasiswa juga mengalami revolusi dalam prokrastinasi akademik. Prokastinasi atau lebih dikenal dengan perilaku menunda-nunda pekerjaan dapat dialami oleh siapa saja. Hal ini merupakan hal yang biasa tetapi dapat berakibat buruk kalau kita menanamkannya dalam diri (Arumsari, 2009). Seseorang dikatakan dapat mengatur waktunya dengan bijaksana, ketika dapat membagi aktivitas-aktivitasnya dalam waktu dan proporsi yang tepat sesuai dengan prioritas dan kepentingannya. Keuntungan yang dapat diberikan dari manajemen waktu yang baik adalah selesainya pekerjaan atau aktivitas, sehingga prokrastinasi khususnya dalam bidang akademik tidak terjadi.

Pengaturan waktu yang kurang baik dalam mengerjakan tugas seperti prokrastinasi, akan berdampak negatif bagi individu. Prokrastinasi dapat dikatakan sebagai suatu penundaan atau kecenderungan menunda-nunda memulai suatu kerja, namun prokrastinasi juga bisa dikatakan sebagai penghindaran tugas dan ketakutan untuk gagal dalam mengerjakan tugas (Ghufron dalam Andarini, \& Fatma, 2013). Burka dan Yuen menyatakan bahwa prokrastinasi terjadi pada semua individu tanpa memandang usia, jenis kelamin, atau statusnya sebagai pekerja atau pelajar (Tondok dkk, 2008). Prokrastinasi tidak saja terjadi di dunia kerja, namun juga banyak terjadi di kalangan pelajar atau mahasiswa.

Hal ini diperburuk lagi dengan adanya pandemi Covid 19 di Indonesia. Covid 19 merupakan penyakit yang disebabkan oleh virus severe acute respitory syndrome coronavirus 2 (SAR-CoV-2), yang dapat menyebabkan gangguan sistem pernafasan, mulai dari gejala ringan seperti flu, hingga infeksi paru-paru. Covid 19 berdampak luas pada masyarakat, termasuk sektor pendidikan. Melalui Surat Edaran Nomor 3 Tahun 2020 Tentang Pencegahan Covid 19 pada satuan pendidikan, Menteri Pendidikan dan Kebudayaan meminta pembelajaran dilakukan di rumah masing-masing.

Suasana belajar di rumah atau Pembelajaran Jarak Jauh (PJJ) yang dilaksanakan tidak serta merta mudah dilaksanakan. Banyak kendala teknis dan non teknis yang muncul. Kendala teknis seperti terbatasnya jaringan dan kuota bagi siswa, guru, mahasiswa dan dosen mempengaruhi proses pendidikan. Masalah non teknis seperti sulitnya konsentrasi data belajar di rumah, tanpa materi yang cukup, tugas menumpuk membuat mahasiswa mudah meninggalkan tugas utamanya.

Penelitian Hana Hanifah Fauziah (2015) menyatakan bahwa ada tiga factor yang mempengaruhi prokrastinasi akademik pada mahasiswa, yaitu fisik, psikis, dan lingkungan. Faktor yang paling besar adalah factor lingkungan, yaitu lingkungan pergaulan mahasiswa yang paling besar mempengaruhi seorang mahasiswa untuk melakukan prokrastinasi. 
Lingkungan yang kurang mendukung dalam penyelesaian tugas-tugas kuliah akan menghambat mahasiswa untuk focus menyelesaikan tugasnya.

Penelitian Siti Muyana (2017), dengan judul Prokrastinasi Akademik Dikalangan Mahasiswa Program Studi Bimbingan Konseling. Hasil penelitian menunjukkan bahwa prokrastinasi mahasiswa sangat tinggi yang disebabkan oleh beberapa hal seperti factor sosial, gangguan perhatian (lingkungan), manajemen waktu, inisiatif, pribadi dan kemalasan. Penelitian ini menunjukkan banyak factor yang membuat mahasiswa mengalihkan perhatiannya pada hal lain diluar tugas utamanya. Berdasarkan fenomena diatas maka penulis tertarik untuk melakukan penelitian Media Sosial dan Dampaknya terhadap Prokrastinasi Akademik Mahasiswa Saat Pandemi Covid19.

\section{Literatur Review}

\section{Media Baru}

Media baru adalah media yang berbasis internet dengan menggunakan komputer dan telepon genggam canggih. Dua kekuatan utama perubahan awalnya adalah komunikasi satelit dan pemanfaatan komputer. Kunci untuk kekuatan komputer yang besar sebagai sebuah mesin komunikasi terletak pada proses digitalisasi yang memungkinkan segala bentuk informasi dibawa dengan efisien dan saling berbaur, Carey dalam (McQuail, 2011).

\section{Instagram}

Instagram adalah salah satu media sosial yang banyak diminati oleh masyarakat termasuk mahasiswa. Instagram merupakan aplikasi berbagi foto dan video yang memungkinkan pengguna mengambil foto dan video dan membagikannya kembali kepada orang lain. Banyak fitur yang ditawarkan oleh Instagram yang mengundang minta mahasiswa untuk terus mengakses dan mengikuti akun dan postingan yang ada dalam Instagram.

\section{Prokrastinasi}

Prokrastinasi adalah prilaku menunda pekerjaan utama untuk melakukan pekerjaan ringan dan menyenangkan. Prokrastinasi merupakan tindakan yang tidak bisa mengatur waktu sendiri atau memotivasi diri sendiri untuk dapat menyelesaikan tugas tatau pekerjaannya sendiri. Menurut Timothy Phychyl dari Carleton University Canada prokrastinasi adalah permasalahan regulasi diri. Menurutnya, seseorang mengetahui apa saja yang harus dikerjakan, tetapi tidak dapat mendorong diri sendiri untuk melakukan usaha tersebut. Mereka lebih senang mengerjakan hal-hal yang mudah dan menyenangkan, dan menunda pekerjaan atau tugas utama mereka. 


\section{Covid 19}

Covid 19 merupakan penyakit yang disebabkan oleh virus severe acute respitory syndrome coronavirus 2 (SAR-CoV-2), yang dapat menyebabkan gangguan system pernafasan, mulai dari gejala ringan seperti flu, hingga infeksi paru-paru. Virus ini berasal dari Wuhan Cina yang muncul diakhir tahun 2019. Virus ini mulai dikenal di Indonesia pada bulan Maret 2020, ketika ada dua orang yang terinfeksi virus ini.

\section{Teori Uses and Gratification}

Teori Penggunaan dan Pemenuhan Kebutuhan menggunakan pendekatan ini berfokus terhadap audiens member. Dimana Teori ini mencoba menjelaskan tentang bagaimana audiens memilih media yang mereka inginkan. Dimana mereka merupakan audiens / khalayak yang secara aktif memilih dan memiliki kebutuhan dan keinginan yang berbeda-beda di dalam mengkonsumsi media. Menurut para pendirinya, Elihu Katz, Jay G. Blumlerm dan Michael Gurevitch, Uses and Gratifications meneliti asal mula kebutuhan secara psikologis dan sosial, yang menimbulkan harapan tertentu dari media massa atau sumber-sumber lain, yang membawa pada pola terpaan media yang berlainan, dan menimbulkan pemenuhan kebutuhan dan akibat-akibat lain. Pendekatan ini secara kontras membandingkan efek dari media dan bukan apa yang media lakukan pada pemirsanya (kritik akan teori jarum hipodermik, dimana pemirsa merupakan objek pasif yang hanya menerima apa yang diberi media).

Uses and gratifications untuk pertama kalinya diperkenalkan oleh Herbert Blumer dan Elihu Katz pada tahun 1974 dalam buku "The Uses Of Mass Communications: Current Perspektives On Gratifications Research". Penelitian diarahkan kepada jawaban pertanyaan"apa yang dilakukan media untuk khalayak. (Edie Santoso;Mite Setiansah 2010 :106) Salah satu dari teori komunikasi massa yang populer dan sering digunakan sebagai kerangka teori dalam mengkaji realitas komunikasi massa adalah Uses and Gratifications. Pendekatan Uses and Gratifications menekankan riset komunikasi massa pada konsumen pesan atau komunikasi dan tidak begitu memperhatikanmengenai pesannya.

\section{Method}

Subjek penelitian yang dimaksud adalah subjek yang telah dipilih oleh peneliti untuk diteliti secara mendalam dan terstruktur. Dalam penelitian yang dibuat ini, subjek penelitian ini adalah Mahasiswa Fakultas Ilmu Komunikasi Universitas Gunadarma yang aktif menggunakan Instagram. Sedangkan objek penelitian merupakan hal yang ingin diteliti. Objek penelitian ini adalah bagaimana Peran Media Sosial Instagram Terhadap Prokrastinasi Akademik Bagi Mahasiswa. Lokasi penelitian secara virtual menggunakan 
google form yang ditujukkan kepada mahasiswa Ilmu Komunikasi Universitas Gunadarma angkatan 2016. Waktu Penelitian adalah bulan April - Juni 2020. Pilihan waktu ini didasarkan pada Perkembangan Covid 19 di Indonesia, dan diikuti kebijakan PJJ oleh pemerintah Indonesia.

Sesuai dengan permasalahan yang dipilih dalam penelitian ini maka pendekatan penelitian yang digunakan adalah pendekatan kualitatif. Menurut Pawito (2007: 35) penelitian komunikasi dimaksudkan untuk mengemukakan gambaran atau pemahaman mengenai bagaimana suatu gejala realitas komunikasi terjadi. Jenis penelitian yang digunakan adalah jenis deskriptif dengan tujuan membuat deskripsi secara sistematis, factual dan aktual tentang fakta-fakta dan sifat-sifat objek tertentu. Paradigma yang digunakan di dalam penelitian ini adalah paradigma kontruktivis dimana realitas merupakan kontruksi sosial. Kebenaran suatu realitas bersifat relative. Berlaku sesuai konteks spesifik yang dinilai relevan oleh pelaku sosial. Peneliti dan objek realitas yang diteliti merupakan kesatuan realitas.Konstruktivisme menyatakan bahwa individu tidak pernah memahami realitas yang sesungguhnya secara intologis, melainkan lebih kepada melihat bagaimana kita menjadi tahu akan suatu hal. Peneliti menggunakan paradigma kontruktivisme dalam penelitian yang bersangkutan, dimana paradigma ini mengasumsikan bahwa individu yang ada selalu memahami dunia dimana mereka hidup (Creswell, 2009).

Menurut Sugiyono (2012: 224) teknik pengumpulan data merupakan cara paling strategis yang digunakan peneliti umtuk mengumpulkan data dalam penelitian. Teknik pengumpulan data yang dipakai oleh peneliti untuk memperoleh data dan informasi dari informan guna memperoleh data yang lengkap, tepat, dan valid sehingga tujuan penelitian yang dilakukan dapat terpenuhi. Adapun teknik pengumpulan data yang dilakukan yaitu peneliti mengamati komunikasi yang terjadi pada mahasiswa fikom universitas gunadarma yang mengalami prokrastinasi akademik yang disebabkan oleh sosial media Instagram. Peneliti menggunakan wawancara tidak terstruktur, agar mahasiswa Fikom Universitas Gunadarma dapat menceritakan semua pengalaman mereka dengan jelas saat mengalami prokrastinasi akademik dikarenakan media sosial instagram terutama saat Pandemi Covid 19. Sehingga apa yang ingin ditemukan dalam pertanyaan wawancara tersebut dapat terpenuhi. Dokumentasi adalah data pendukung yang dikumpulkan sebagai penguatan data observasi dan wawancara. Penelitian mengumpulkan berbagai bahan tertulis seperti buku maupun jurnal serta tentunya berbagai sumber lainnya yang dapat mendukung penelitian bersangkutan, peneliti juga akan mendokumentasikan berbagai bentuk seperti rekaman, foto, dan hasil wawancara yang 
mendukung serta permasalahan yang terjadi dalam penelitian dapat terungkap dan diselesaikan.

\section{Result and Discussion}

\section{Prokrastinasi Akademik bagi Mahasiswa}

Menunda-nunda dianggap sebagai hambatan mahasiswa dalam mencapai kesuksesan akademis karena dapat menurunkan kualitas dan kuantitas pembelajaran, menambah tingkat stres, dan berdampak negatif dalam kehidupan mahasiswa. Dampak yang terjadi akibat prokrastinasi akademik seringkali tidak menjadi perhatian khusus bagi sebagian mahasiswa.

Munculnya prokrastinasi akademik dalam diri mahasiswa diprediksi tidak terjadi begitu saja, namun terdapat penyebab yang melatar belakangi. Hal ini juga di tambah dengan kondisi pandemic covid 19 yang terjadi saat ini. Kondisi pembelajaran yang dilakukan dari rumah lebih menyulitkan mahasiswa untuk menerima materi dan mengerjakan tugasnya. Tugas-tugas yang diberikan oleh dosen baik melalui perkuliahan online virtual class dan menggunakan video conference menambah sikap prokastinasi mahasiswa. Kejenuhan di rumah, belajar sendiri menjadi pemicu sikap prokastinasi semakin kuat menempel pada mahasiswa tingkat akhir.

Menurut Ferrari, Johnson, \& Mc Cown (1995) menyebutkan bahwa penyebab perilaku prokrastinasi adalah:

\section{Pikiran Irrasional dari Prokrastinator}

Irrasional adalah berlawanan atau tidak selaras. Pikiran irrasional yang dimaksud adalah pikiran bahwa sesuatu harus dikerjakan dengan hasil yang sempurna itu irasional. Karena hasil sesuatu yang dilakukan itu abstrak dan penilaian bisa saja meleset. Dalam kasus penelitian ini narasumber atau para prokrastinator mempunyai sifat yang beragam dari yang terobsesi sampai yang tidak peduli dengan hasilnya. Menurut keenam responden yang diteliti semuanya menjawab hampir sama soal hal ini yaitu, jelas mereka ingin maksimal tapi tidak sampai ke titik terobsesi.

\section{Adanya Kecemasan karena Kemampuannya Dievaluasi}

Kecemasan atau ketakutan seseorang akan dinilai atau dijudge banyak juga mempengaruhi para informan. Kecemasan dalam arti banyak hal. Cemas akan salah mengerjakan tugas akhir, cemas kalau tidak dapat mengerjakannya, dan cemas akan nilai yang diberikan tidak sesuai harapan, tidak lulus dan lain-lain. Mereka ketakutan akan kegagalan, susah mengambil keputusan, atau karena membutuhkan bantuan orang lain untuk mengerjakan tugasnya. Padahal sebuah evaluasi baik dan perlu dilakukan karena 
banyak alasan yang positif. Misalnya introspeksi dapat dilakukan ketika evaluasi sudah diberikan. Satu nara sumber mengaku tidak mencemaskan karena dia berfikir bahwa hanya selesai saja itu sudah cukup untuknya.

\section{Malas, Kesulitan Mengatur Waktu dan Tidak Menyukai Tugasnya.}

Malas merupakan sifat umum dari seorang mahasiswa. Mahasiswa yang cenderung menginnginkan semuanya beres tanpa ada usaha yang maksimal juga mempengaruhi mahasiswa dalam manejemen waktu. Ditambah tugas yang diberikan tidak sesuai dengan harapan mahasiswa atau bisa dibilang sulit. Tiga faktor tersebut mendorong keras seseorang khususnya enam informan dalam melakukan prokrastinasi akademik. Jaman yang sudah berkembang, teknologi, sosial media yang bersifat adiktif akan menambah rasa malas yang ada dalam diri seorang mahasiswa. Faktor ini banyak mempengaruhi para informan yang diteliti.

\section{Adanya Reward dan Punishment}

Punishment atau hukuman yang dimaksud adalah sanksi yang diberikan oleh penguji yang bersangkutan, dan reward atau penghargaan yang dimaksud yaitu ketika tugas yang diberikan dapat dikerjakan sesuai kaidah yang ditentukan. Tapi sebaliknya, juga dapat menyebabkan prokrastinasi sehingga merasa lebih aman jika tidak melakukan dengan segera karena dapat menghasilkan sesuatu yang tidak maksimal. Alasan merasakan aman yaitu kurang ketatnya peraturan yang ditentukan dari penguji yang bersangkutan. Narasumber atau para informan cenderung merasakan perasaan tidak peduli dengan adanya penghargaan atau hukuman yang diberikan. Tapi, informan tetap memutuskan untuk tidak mengerjakan tugas yang diberikan, walaupun 4 diantaranya bukan karena hukuman atau penghargaan.

\section{Adanya faktor lingkungan}

Yaitu kurangnya atau rendahnya pengamatan dari lingkungan seperti keluarga atau di lingkungan kampus juga menyebabkan seseorang melakukan prokrastinasi. Seseorang akan cenderung rajin mengerjakan sesuatu apabila ada yang mengawasi dirinya dan sebaliknya jika tidak ada yang mengawasi, mahasiswa akan merasa lebih bebas sehingga bisa memutuskan kapan harus mengerjakan bahkan mungkin tidak akan mengerjakannya. Selain itu, faktor teman bergaul juga mempengaruhi sikap prokrastinasi. Para informan yang diteliti mengatakan bahwa lingkungan pertemanan nya cenderung mendukung atau bahkan membuat mereka melakukan prokrastinasi akademik sadar atau tidak sadar. Sebaliknya ke 6 informan mempunyai lingkungan keluarga yang tidak mendukung mereka sama sekali untuk melakukan prokrastinasi akademik. 


\section{Penundaan Tugas}

Tugas yang menumpuk, terlalu banyak dan harus segera dikerjakan, membuat terjadinya penundaan satu tugas, sehingga menyebabkan tugas lain tertunda. Sebagai mahasiswa pasti memiliki banyak tugas yang harus dituntaskan. Terbukti dari ke 6 informan yang mengaku bahwa tugas yang diberikan banyak sehingga menumpuk. Jika dilihat dari pelaksanaan PJJ yang cenderung mendadak dan kurang persiapan hal ini dapat dimaklumi, sehingga sekolah, Unversitas, Guru, Dosen sedang menyiapkan metode pembelajaran terbaik kepada para siswa.

Wolters (2003 : 179) menyatakan bahwa prokrastinasi merupakan sikap sadar dari mahasiswa untuk menunda tugas utamanya secara berulang-ulang (kompulsif) sehingga muncul perasaan tidak nyaman, cemas, dan merasa bersalah. Penelitian Hana Hanifah Fauziah (2015) menjelaskan bahwa terdapat tiga faktor yang mempengaruhi prokrastinasi akademik pada mahasiswa, yaitu fisik, psikis, dan lingkungan. Faktor yang paling besar adalah faktor lingkungan, yaitu lingkungan pergaulan mahasiswa yang paling besar mempengaruhi seorang mahasiswa untuk melakukan prokrastinasi. Lingkungan yang kurang mendukung dalam penyelesaian tugas-tugas kuliah akan menghambat mahasiswa untuk fokus menyelesaikan tugasnya. Hal ini diperparah dengan munculnya Pandemi Covid 19 yang merubah pembelajaran dengan cara daring. Pembelajaran daring yang dilaksanakan secara cepat dengan sedikit persiapan menyebabkan ketidaksiapan perguruan tinggi, terutama dosennya, sehingga alternative pemberian tugas menjadi pilihan untuk mahasiswa.

Penelitian Siti Muyana (2017), dengan judul Prokrastinasi Akademik Dikalangan Mahasiswa Program Studi Bimbingan Konseling. Hasil penelitian menunjukkan bahwa prokrastinasi mahasiswa sangat tinggi yang disebabkan oleh beberapa hal seperti factor sosial, gangguan perhatian (lingkungan), manajemen waktu, inisiatif, pribadi dan kemalasan. Penelitian ini menunjukkan banyak factor yang membuat mahasiswa mengalihkan perhatiannya pada hal lain diluar tugas utamanya. Kejenuhan karena belajar di rumah, peluang menggunakan smartphone semakin lama membuat gangguan mahasiswa untuk melakukan prokrastinasi semakin besar. Kegiatan belajar secara online membuat mahasiswa semakin intens menggunakan gaway mereka untuk belajar dan ngobrol virtual dengan teman-temannya.

Pengguna (Uses) isi media untuk mendapatkan pemenuhan (Gratification) atas kebutuhan seseorang atau Uses and Gratification salah satu teori dan pendekatan yang sering digunakan dalam komunikasi. Teori dan pendekatan ini tidak mencakup atau mewakili keseluruhan proses komunikasi karena sebagian besar pelaku audience hanya dijelaskan 
melalui berbagai kebutuhan (needs) dan kepentingan (interest) mereka sebagai suatu fenomena mengenai proses penerimaan (pesan media). Teori ini melihat bahwa manusia memiliki kewenangan memilih media mana yang cocok untuk digunakan, dilihat atau diikuti. Banyak alasan yang membuat orang memilih suatu media untuk mendapatkan informasi dan hiburan

Pada tahun 2016 terdapat 4 media sosial yang paling banyak digunakan oleh masyarakat Indonesia, yaitu, Facebook, Instagram, Twitter, dan Path. Facebook menempati urutan pertama disusul Instagram kemudian masuk Twitter dan Path. Kompasiana.com (6 Januari 2017). Meski Facebook menempati peringkat pertama namun dalam penelitian ini mengambil Instagram karena fitur Instagram lebih lengkap dibandingkan dengan Facebook. Fitur-fitur yang terdapat di Instagram yaitu, Instagram stories, siaran langsung, foto, dan video, sedangkan Facebook hanya memiliki fitur siaran langsung, foto, dan video.

Selain karena fitur Instagram lebih lengkap kebanyakan mahasiswa khususnya di Fakultas Ilmu Komunikasi Universitas Gunadarma lebih memilih Instagram dan aktif menggunakan media sosial tersebut. Pada tahun 2010, Kevin dan Mike menciptakan aplikasi web bernama Burbn akan tetapi fitur-fitur aplikasi terlalu banyak sehingga pengguna kesulitan dalam pengoperasiannya. Lalu mereka membuat aplikasi baru bernama instagram yang hanya menggunakan tiga fitur, yaitu foto, suka dan komentar. Pengguna Instagram tidak perlu repot untuk menggunakan aplikasi sosial media ini. Seiring perkembagan teknologi, Instagram menambakan fiturnya dengan munculnya Instagram stories dan siaran langsung (Aditia : 2015). Fitur sebelumnya di kalangan remaja hanya aktif menggunakan 3-4 kali postingan dalam seminggu maka dengan adanya fitur Instragram stories pengguna Instagram lebih intens mengunggah foto dan video dengan fitur tersebut. Evolusi yang dialami media sosial khususnya Instagram, membuat media sosial ini makin terlihat menarik secara interface dan makin multifungsi karena fitur-fitur yang dimiliki Instagram itu sendiri dan hal itu sebuah hal yang positif.

\section{Conclussion}

Prokrastinasi menjadi fenomena yang menarik di kalangan mahasiswa dalam menyelesaikan tugas-tugas pokok perkuliahan. Mahasiswa cenderung lebih mengutamakan kegiatan ringan, menghibur daripada menyelesaikan tugas kuliahnya. Kejenuhan belajar saat diberlakukannya Pembelajaran Jarak jauh (PJJ) sebagai akibat Pandemi Covid19 menjadi factor utama mahasiswa melakukan prokrastinasi akademik. Mahasiswa mengetahui bahwa tindakan prokrastinasi adalah tidak tepat, dan mereka menyadari bahwa mereka sudah mengesampingkan tugas pokoknya, sehingga berpengaruh pada prestasi akademiknya. Hal ini 
sejalan dengan Teori yang digunakan yaitu Uses and Gratification bahwa audiens dalam hal ini Mahasiswa secara aktif memilih kebutuhan yang diinginkan yaitu terkait dengan media pembelajaran untuk meningkatkan pengetahuan dan prestasi di bidang akademik.

\section{References}

Arumsari Dwi, A. Dan Sugito Muzaqi. Prokrastinasi Akademik Pada Mahasiswa Yang Bekerja.

Hervani Gilar, S. (2013). Penggunaan Sosial Media dan Dampak Terhadap Prokrastinasi Akademik Pada Mahasiswa Universitas Negeri Yogyakarta Angkatan 2013.

Jocom, N. (2013). Peran Smartphne dalam Menunjang Kinerja Karyawan Bank Prismadana (Studi Pada Karyawan Bank Prismadana Cabang Airmadidi). Journal “Acta Diurna" Vol.I.No.I

Lanani, K. (2013). Belajar Berkomunikasi dan Komunikasi Untuk Belajar dalam Pembelajaran Matematika. Jurnal Ilmiah Program Studi Matematika. Vol.2 No.1

Muyana, S. (2018). Prokrastinasi Akademik Dikalangan Mahasiswa Program Studi Bimbingan dan Konseling. 8 (1), 45-52.

Nafeesa. (2018). Faktor-faktor yang mempengaruhi Prokrastinasi Akademik Siswa yang Menjadi Anggota Organisasi Siswa Intra Sekolah. Anthropos:Jurnal Antropologi Sosial dan Budaya. 4(1)(2018):53-67

Nalim. (2015). Analisis Faktor yang Mempengaruhi Motivasi Belajar Mahasiswa Yang Kuliah Sambil Bekerja.

Nasrullah, Rulli. (2015). Media Sosial Perspektif Komunikasi, Budaya dan Sosioteknologi. Bandung: Simbiosa Rekatama Media

Prihandika, D. (2017). Hubungan Antara Kematangan Emosi Dengan Prokrastinasi Dalam Penyusunan Skripsi Mahasiswa Fakultas Psikologi Universitas Muhammadiyah Surakata.

Pychyl, T. A., \& Flett, G. L. (2012). Procrastination and self-regulatory failure: An introduction to the special

issue. Journal of Rational-Emotive \& Cognitive-Behavior Therapy, 30, 203-2012.

Ratnamulyani Atikah, I. Dan Beddy Iriawan Maksudi. (2018). Peran Media Sosial Dalam Peningkatan Partisipasi Pemilih Pemula Dikalangan Pelajar Di Kabupaten Bogor. Jurnal Ilmu-Ilmu Sosial dan Humaniora.Vol.20 No.2:154-161.

Saraswati,P. (2017). Strategi Self Regulated Learning Dan Prokrastinasi Akademik Terhadap Prestasi Akademik. Jurnal Psikologi Ilmiah. DOAJ:2541-2965

Setiawan Rudy, (2013). Kekuatan New Media Dalam Membentuk Budaya Populer di Indonesia (Studi Tentang Menjadi Artis Dadakan Dalam Mengunggah Video Musik Di Youtube) e.Jurnal Ilmu Komunikasi, 1 (2):355-374.

Setiadi, A. (2016). Pemanfaatan Media Sosial untuk Efektifitas Komunikasi 
Siregar, Ade Rahmawati. (2006). Motivasi Berprestasi Mahasiswa Ditinjau Dari Pola Asuh. Diakses dari http://repository.usu.ac.id/handle/123456789/733 4, pada tanggal 5 Juni 2011.

Siallagan, DF. (2011). "Fungsi dan Peranan Mahasiswa", www.academia.edu, diakses pada 30 April 2019

Zakirah Almas Marta, D. (2017). Study Tentang Instagram Sebagai Saran Membentuk Citra Diri di Kalangan Mahasiswa Universitas Airlangga. Jurnal S1 Sosiologi Fisip Universitas Airlangga 